\title{
BEBERAPAJENIS IKAN LOKAL YANG POTENSIAL UNTUK BUDIDAYA: Domestikasi, Teknologi Pembenihan, dan Pengelolaan Kesehatan Lingkungan Budidaya
}

\author{
Estu Nugroho"), M. Fatuchri Sukadi*), dan Gleni Hasan Huwoyon**) \\ *) Pusat Penelitian dan Pengembangan Perikanan Budidaya \\ Jl. Ragunan 20, Pasar M inggu, Jakarta Selatan 12540 \\ E-mail: engroho@yahoo.com \\ ** Balai Penelitian dan Pengembangan Budidaya Air Tawar \\ J. Sempur No. 1, Bogor 16154
}

\begin{abstract}
ABSTRAK
Biodiversitas ikan-ikan air tawar lokal asli Indonesia sangat berlimpah namun belum banyak dimanfaatkan dalam budidaya. Pemanfaatan secara langsung masih dalam taraf penangkapan di alam yang dikhawatirkan dapat membahayakan populasinya di alam. Salah satu alternatif untuk pencegahannya adalah dengan upaya meningkatkan budidaya dan mengurangi penangkapan yang berlebihan. Langkah pertama yang dibutuhkan adalah melakukan do mestikasi untuk mendapatkan teknologi pembenihannya dan upaya pengelolaan lingkungan yang dibutuhkannya. Sekitar 20 jenis ikan lokal asli Indonesia telah dimanfaatkan dalam budidaya ikan konsumsi, sedangkan teknologi yang telah berhasil dikembangkan tercatat pada 7 jenis ikan air tawar seperti ikan baung, jelawat, nilem, kancra, tawes, belida, dan betutu.
\end{abstract}

KATA KUNCl: ikan lokal, potensial, pembenihan

\section{PENDAHULUAN}

Indonesia mempunyai keanekaragaman jenis ikan yang meliputi sekitar 8.500 jenis dari sekitar 20.000 jenis ikan yang ada di dunia (M inistry of National Development Planning, 1993). Kegiatan pemanfaatan plasma nutfah melalui pembudidayaan ikan telah dilakukan beberapa ratus tahun yang lalu, yaitu ikan bandeng (Chanos chanos) yang dipelihara di tambak pada zaman Majapahit. Pembudidayaan ikan mas (Cyprinus carpio) pertama kali dilakukan, diperkirakan pada abad ke-19 melalui domestikasi ikan-ikan dari Cina maupun Eropa.

Dewasa ini, produksi ikan dari hasil budidaya ikan air tawar sebagian besar $(75,71 \%$ disumbangkan oleh komoditas-komoditas ikan introduksi yang sudah lama didomestikasi di Indonesia yaitu ikan mas, nila, lele dumbo, dan patin hypop (Pusat Data Statistik dan Informasi, 2008). Produksi ikan-ikan lokal asli Indonesia tidak terinci tercatat, namun dikelompokkan ke dalam ikan lainnya yang tercatat sekitar $20 \%$ dari total produksi ikan air tawar pada tahun 2008.

Perkembangan yang luas budidaya ikan non asli Indonesia (introduksi) yang sudah terdomestikasi baik ini di beberapa daerah menjadi salah satu penyebab mulai jarang bahkan sulitnya beberapa jenis ikan lokal asli Indonesia yang dapat ditemui di perairan umum, seperti ikan tambra (Tor tambroides Bleeker, 1854) di Hulu DAS Barito (Haryono \& Subagja, 2008); ikan belida (Notopterus) dan patin sungai (Pangasius nasutus) serta ikan jelawat (Leptobarbus hoeveni) dianggap sudah jarang ditemukan (Petrus et al., 2008); ikan betutu (Oxyeleotris marmorata), dan tebirin (Belodontichthys dinema) (Utomo, 2008).

Salah satu alternatif untuk menjaga biodiversitas ikan-ikan lokal asli Indonesia melalui konservasi jenis di tingkat pembudidaya (on farm conservation) adalah dengan cara mendomestikasikan dan membudidayakannya. Pengembangan budidaya berbasis ikan lokal ini dapat dijadikan pula sebagai upaya dalam mengembangkan budidaya ramah lingkungan, menanggulangi kemiskinan, dan menyediakan pangan bagi masyarakat lokal.

Budidaya ramah lingkungan dalam arti ikut membantu pemeliharaan ekosistem tempat ikan lokal biasa hidup yang umumnya selalu diikuti dengan kearifan lokal seperti ikan garing di Suaka Lubuk Larangan, Sumatera Barat. Selain itu, sistem perikanan berbasis budidaya merupakan salah satu hal yang biasa dilakukan dengan ikan-ikan lokal sebagai bahan untuk penebaran di alam sehingga dapat menjadikan mata pencarian tambahan bagi masyarakat sekitar yang secara tidak langsung akan dapat mengurangi kemiskinan sekaligus sebagai sumber protein hewani yang dibutuhkan masyarakat. 
Dalam proyeksi produksi perikanan budidaya nasional sampai tahun 2014, ikan lokal termasuk ke dalam kelompok jenis ikan lainnya yang belum mendapatkan perhatian untuk diunggulkan. Walaupun demikian, proyeksi peningkatan ikan lainnya ini (188\%tahun) lebih tinggi dari proyeksi kenaikan produksi ikan unggulan seperti ikan mas (138\%//tahun), gurame (127\%//tahun), dan bahkan terhadap udang windu (182\%/tahun), serta kakap (185\%/tahun) (Murdjani, 2010). Sebagai perbandingan, di Cina yang sudah demikian tinggi hasil akuakulturnya (tahun 2006: 36,9 juta ton), komposisi ikan yang bukan asli Cina hanya sekitar $11,7 \%(2,5$ juta ton) (Liu \& Li, 2010).

Langkah awal yang perlu dilakukan dalam upaya membudidayakan ikan lokal Indonesia adalah dengan menentukan jenis ikan yang potensial. Pengembangan ikan lokal akan sangat tergantung di antaranya pada pemasaran ikan tersebut, tersedianya benih dan teknologi budidaya, serta dukungan kelembagaan yang ada.

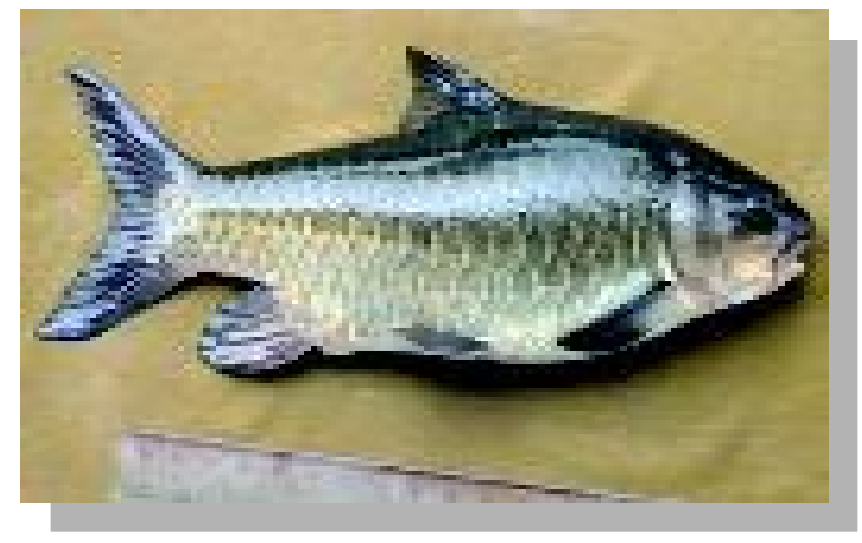

Gambar 1. Ikan Tor sp. yang sudah mulai jarang dijumpai di Kalimantan

\section{Jenis Ikan Lokal Potensial}

Sekitar 21 jenis ikan lokal air tawar (dari 40 jenis komoditas ikan) yang dikembangkan sebagai sumber plasma nutfah untuk kegiatan budidaya dalam rangka menunjang program diversifikasi usaha budidaya pada Direktorat Jenderal Perikanan Budidaya (Nugroho, 2002) tertera pada Tabel 1.

Balai Riset Perikanan Budidaya Air Tawar sejak tahun 2006 mulai melaksanakan evaluasi jenis-jenis ikan lokal yang potensial untuk budidaya melalui kegiatan analisis komoditas melalui diskusi kelompok terfokus (Focus Group Discussion, FGD). Beberapa kriteria yang digunakan untuk menentukan jenis komoditas sebagai ikan potensial adalah pemasaran, ketersediaan benih,
Tabel 1. Jenis ikan air tawar lokal Indonesia yang digunakan dalam budidaya

\begin{tabular}{ll}
\hline \multicolumn{1}{c}{ Nama latin } & Nama lokal \\
\hline Pangasius nasutus & Patin lokal \\
Pangasius djambal & Patin lokal \\
Leptobarbus hoeveni & Jelawat \\
Oxyeleotris marmorata & Betutu \\
Notopterus borneensis & Belida \\
Mystus nemurus & Baung \\
Helostoma temminchii & Kapar/tambakan \\
Anabas testudineus & Betok/papuyu \\
Osphronemus gouramy & Gurami/kalui \\
Tor douronensis & Semah \\
Puntius javanicus & Tawes \\
Puntius schwanefeldi & Lampam \\
Scleropages formosus & Arowana \\
Osteochilus sp. & Kelabau \\
Osteochilus hasselti & Nilem \\
Clarias spp. & Lele-lelean \\
Mystacoleucus padangensis & Bilih maninjau \\
Thynnichthys thinnoides & Benangin \\
Channa sp. & Gabus-gabusan \\
Mugil chepalus & Belanak \\
Chanos chanos & Bandeng \\
\hline
\end{tabular}

teknologi pembudidayaan, keberadaan institusi pengembangan budidaya, dampak terhadap UKM, dan industri budidaya, serta lingkungan bila komoditas dikembangkan dan keunggulan komparatifnya. Penilaian dilakukan dengan skoring disertai pembobotan masingmasing kriteria yang ditentukan sendiri secara langsung oleh stakeholder perikanan budidaya antara lain, pengusaha swasta, pembudidaya, petugas pemerintah, perguruan tinggi, peneliti, dan perekayasa.

Berikut ini hasil dari kegiatan analisis komoditas di daerah Kalimantan (Kalimantan Barat, Kalimantan Timur, Kalimantan Tengah, dan Kalimantan Selatan) dan di daerah Sumatera (Provinsi Riau, Sumatera Selatan, Sumatera Barat, dan Lampung).

Jenis ikan lokal yang diminati oleh stakeholder sebagai ikan potensial budidaya di Pulau Kalimantan sekitar 16 jenis yaitu ikan sapan/lomi (Tor tambroides), kalui/gurami (Osphronemus gouramy), pipih/belida (Chitala sp.), jelawat (Leptobarbus hoeveni), baung (M ystus nemurus), tambakan (Helostome temminckii), betutu (Oxyeleotris marmorata), patin sungai (Pangasius nasutus), kalabau (Osteochilus sp.), toman (Channa sp.), tapah (Wallago sp.), betok (Anabas testudineus), saluang (Rasbora sp.), tambuwuk, sanggang, dan udang galah (M acrobrachium rosenbergii). 
Empat jenis ikan lokal yang menempati urutan teratas dan diperkirakan akan dapat berkembang baik di masyarakat dalam mendorong perkembangan budidaya ikan lokal di daerah setempat antara lain adalah udang galah, betok, jelawat, dan betutu. Keempat jenis ikan ini dijadikan prioritas komoditas di masing-masing daerah di Kalimantan, di samping komoditas nasional yang sudah ditentukan yaitu ikan mas dan nila. Hasil skoring analisis komoditas di daerah Kalimantan Tengah tercantum pada Tabel 2.

Tabel 2. Hasil skoring analisis komoditas ikan lokal di daerah Kalimantan Tengah (2010)

\begin{tabular}{lll}
\hline \multicolumn{1}{c}{ Nama latin } & Nama lokal & Skor \\
\hline Macrobrachium rosenbergii & Udang galah & 440 \\
Leptobarbus hoeveni & Jelawat & 390 \\
Oxyeleotris marmorata & Betutu & 390 \\
Anabas testudineus & Betok, papuyu & 390 \\
Osphronemus gouramy & Kalui/gurami & 350 \\
Helostoma temminchii & Tambakan & 340 \\
Mystus nemurus & Baung & 320 \\
Notopterus sp. & Pipih/belida & 320 \\
Tor tambroides & Sapan/lomi & 290 \\
Channa sp. & Toman & 280 \\
Rasbora sp. & Saluang & 270 \\
Wallago sp. & Tapah & 260 \\
Puntius bulu & Sanggang & 260 \\
Pangasius nasutus & Patin sungai & 250 \\
Osteochilus sp. & Kalabau & 160 \\
Cyclochrilichthys apogon & Tambuwuk & 110 \\
\hline
\end{tabular}

Secara garis besar hasil analisis komoditas tentang ikan lokal yang potensial untuk dikembangkan di daerah Sumatera antara lain adalah ikan garing (Tor sorro), belida, gurame, bilih, betutu, rasbora, tawes, tambakan, mujair, baung, nilem, dan udang galah. Empat jenis ikan lokal yang diminati oleh stakeholder sebagai ikan potensial di daerah Sumatera Barat adalah sebagai berikut: ikan gurame, garing, baung, dan rasbora (Gambar 2).

\section{Teknologi Pembenihan}

Unit Pelaksana Teknis (UPT) di bawah Direktorat Jenderal Perikanan Budidaya dan Badan Penelitian dan Pengembangan Kelautan dan Perikanan telah mengembangkan domestikasi, teknologi pembenihan, dan pembesaran beberapa komoditas ikan lokal yang ada di masyarakat. Secara garis besar status domestikasi, teknologi pembenihan dan pembesaran dapat dibedakan menjadi tiga, yaitu: a) teknologi yang telah dikuasai dan mapan serta dikembangkan di masyarakat sebagai suatu usaha perikanan di antaranya adalah teknologi budidaya ikan gurami dan udang galah, b) teknologi budidaya yang telah mantap dan siap untuk dimasyarakatkan di antaranya adalah teknologi budidaya ikan jelawat, c) teknologi budidaya yang sudah dicoba dalam penelitian dan perekayasaan yang sudah menunjukkan keberhasilannya namun belum mantap sehingga belum siap untuk dimasyarakatkan di antaranya teknologi budidaya untuk ikan botia dan papuyu (Nugroho, 2002).

Sedangkan tim BRPBAT untuk analisis komoditas mendapatkan informasi tentang teknologi pembenihan ikan-ikan lokal di daerah Kalimantan dan Sumatera. Adapun status teknologi di antaranya adalah sebagai berikut: a) teknologi budidaya yang mapan pada komoditas ikan gurame dan udang galah, b) teknologi budidaya siap dikembangkan pada komoditas ikan jelawat, tambakan, betutu, dan betok, sedangkan ikan jenis lainnya masih dalam taraf, c) teknologi yang perlu untuk dimantapkan lagi sebelum dikembangkan di masyarakat.

Nugroho \& Kristanto (2008), menjelaskan teknologi pembenihan dan pembesaran 15 ikan popular di Indonesia, 7 di antaranya adalah untuk ikan lokal yaitu ikan baung, jelawat, betutu, nilem, kancra, belida, dan tawes. Status teknologi dari masing-masing komoditas tertera pada Tabel 3.

\section{Pengelolaan Kesehatan Lingkungan Budidaya}

Secara definisi, penyakit merupakan suatu keadaan fisik, morfologi dan atau fungsi yang mengalami perubahan dari kondisi normal karena beberapa penyebab yaitu dari dalam (internal) dan luar (eksternal) (Direktorat Kesehatan Ikan dan Lingkungan, 2009). Timbulnya penyakit pada ikan merupakan interaksi kontribusi secara bersamaan faktor-faktor ketahanan ikan/inang, sifat jasad patogen dan keadaan lingkungan (Anderson, 1974).

Penyakit yang disebabkan oleh faktor eksternal terdiri atas: a) penyakit non infeksius yang disebabkan oleh faktor lingkungan, mal-nutrisi, dan genetis, b) penyakit infeksi yang disebabkan oleh patogen baik yang berupa jamur, parasit, bakteri, dan virus (Direktorat Kesehatan Ikan dan Lingkungan, 2009).

Pencegahan merupakan salah satu alternatif terbaik yang dilakukan dalam menjaga kesehatan ikan. Untuk ikan lokal yang baru didomestikasi maka pengelolaan faktor lingkungan merupakan faktor utama yang perlu diperhatikan. Pengelolaan faktor lingkungan merupakan upaya semaksimal mungkin untuk memelihara lingkungan tidak berubah atau sesuai dengan yang dibutuhkan ikan 


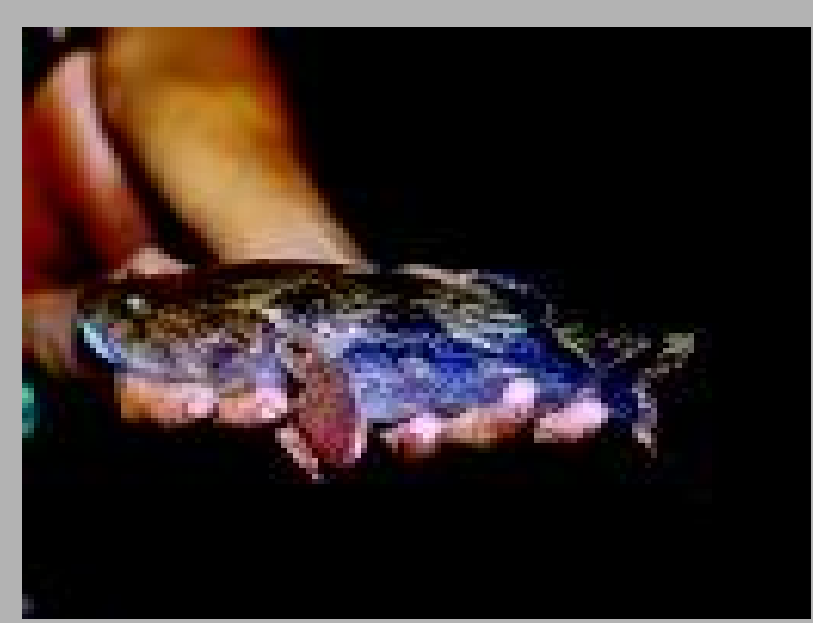

Ikan betutu

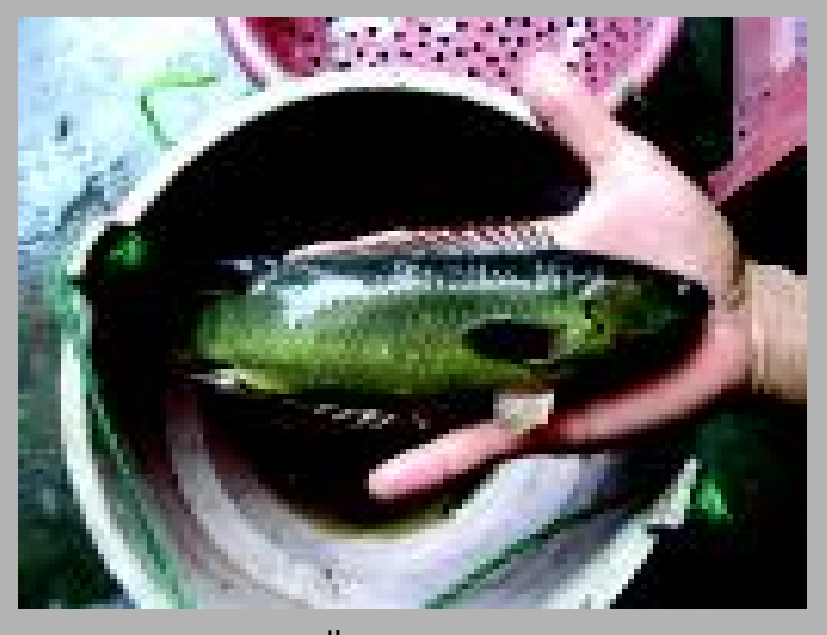

Ikan papuyu

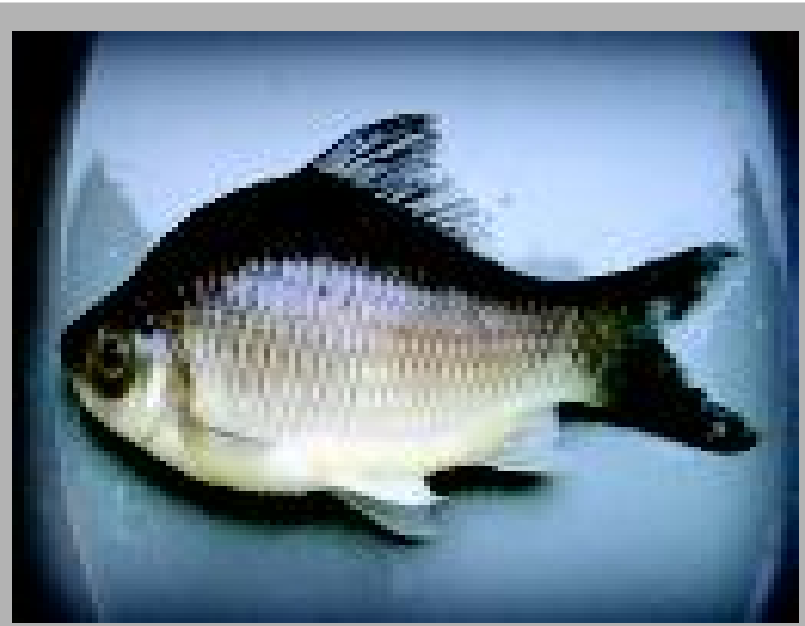

Ikan kelabau hitam

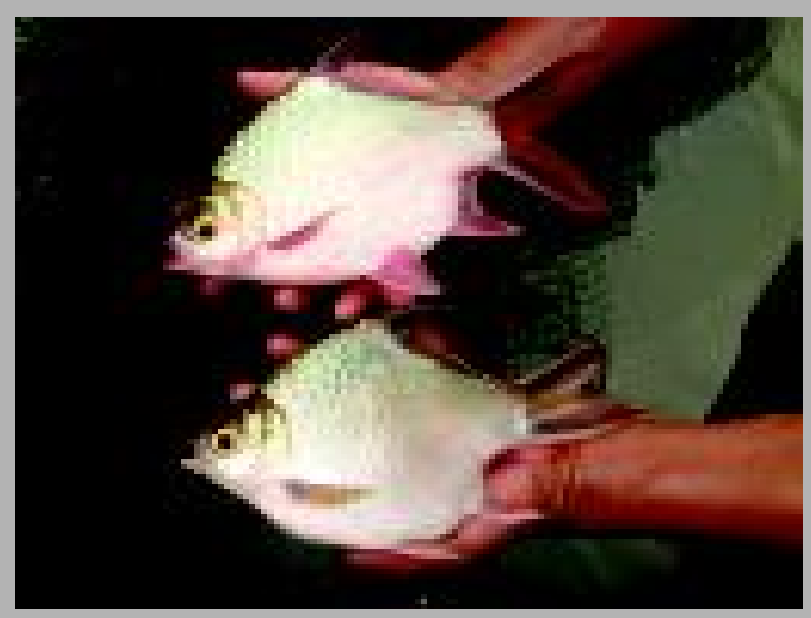

Ikan tengadak

Gambar 2. Beberapa jenis ikan lokal yang ada di Kalimantan dan Sumatera

Tabel 3. Jenis ikan dan status teknologi pembenihannya

\begin{tabular}{|c|c|}
\hline Jenis ikan & Teknologi pembenihan \\
\hline Baung & $\begin{array}{l}\text { Induce breeding , menggunakan hormon ovaprim, dosis } 0,9 \mathrm{~mL} / \mathrm{kg} \text { induk. } \\
\text { Produksi benih }=20.000-30.000 / \mathrm{kg} \text { induk }\end{array}$ \\
\hline Jelawat & $\begin{array}{l}\text { Induce breeding , menggunakan hormon ovaprim, dosis } 0,9 \mathrm{~mL} / \mathrm{kg} \text { induk. } \\
\text { Produksi benih }=50.000 / 2,5 \mathrm{~kg} \text { induk }\end{array}$ \\
\hline Nilem & $\begin{array}{l}\text { Induce breeding , menggunakan hormon ovaprim, dosis 0,6 mL/kg induk. } \\
\text { Produksi benih = 1.500-2.000 ekor/induk (ukuran } 100-200 \mathrm{~g} \text { ) }\end{array}$ \\
\hline Kancra & $\begin{array}{l}\text { Induce breeding , menggunakan HCG dan hormon ovaprim, dosis 0,7 mL/kg induk. } \\
\text { Produksi benih = } 300 \text { ekor/induk (ukuran } 2 \mathrm{~kg} \text { ) }\end{array}$ \\
\hline Tawes & Induce breeding, menggunakan ovaprim, dosis $0,3 \mathrm{~mL} / \mathrm{kg}$ induk. \\
\hline Belida & $\begin{array}{l}\text { Pemijahan alami dengan substrat enceng gondok. } \\
\text { Produksi benih }=500 \text { ekor/induk }\end{array}$ \\
\hline Betutu & $\begin{array}{l}\text { Pemijahan alami, dengan substrat tonggak kayu. } \\
\text { Produksi benih = 200-300 ekor/kg induk }\end{array}$ \\
\hline
\end{tabular}



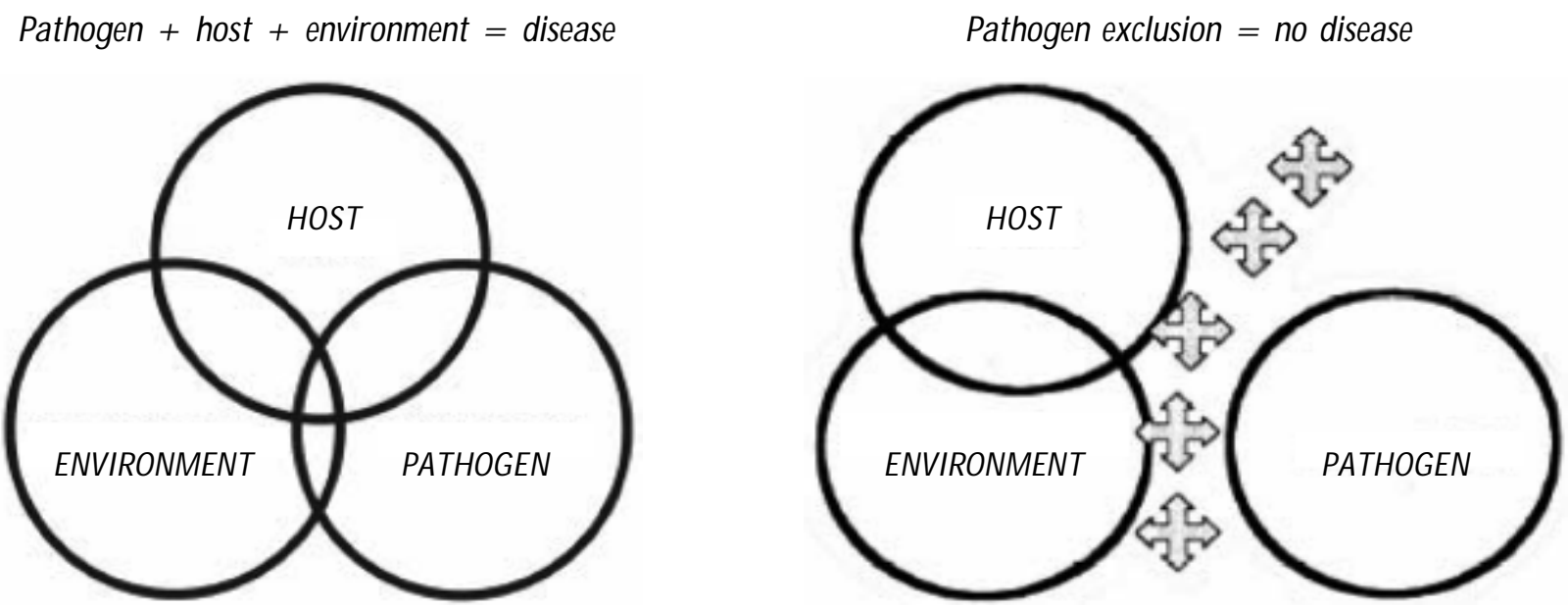

Gambar 3. Interaksi antara ikan, jasad patogen, dan lingkungan penyebab penyakit (Sumber: Liu, APO Meeting Taiwan, 2009)

sehingga ikan tidak stres. Beberapa faktor yang menyebabkan berubahnya keadaan suatu lingkungan adalah polusi, penangkapan berlebihan pada organisme yang masuk dalam rantai makanan, penyebaran jasad patogen dari daerah lain, kecerobohan dalam stocking jenis ikan dan penggunaan bahan berbahaya atau antibiotik pada ikan budidaya di daerah tersebut.

Sumber perubahan lingkungan akibat bahan-bahan polutan baik dari rumah tangga maupun industri sering dijumpai pada perairan daratan. Contoh terkini adalah Waduk Cirata, di mana kualitas airnya jauh memburuk dibandingkan keadaan lingkungan pada awal penggenangannya pada tahun 1984. Pemeliharaan lingkungan dari polutan yang bisa menyebabkan penurunan kualitas air merupakan langkah mutlak yang harus dilakukan misalnya melalui peraturan yang diterbitkan oleh pihak yang berwenang tentang program kebersihan, di samping melakukan sosialisasi pengetahuan dan pendidikan tentang perilaku hidup sehat.

Penangkapan suatu jenis ikan secara berlebihan juga akan mempengaruhi keadaan suatu lingkungan menjadi tidak seimbang lagi. Penangkapan yang berlebihan akan menjadikan rantai makanan yang ada menjadi terputus sehingga dapat menyebabkan suatu jenis ikan menjadi berlimpah. Keadaan ini dapat mempengaruhi pula kondisi lingkungan secara tidak langsung yang bermuara terhadap keberadaan ikan-ikan lokal yang ada di daerah tersebut. Pengaturan alat tangkap baik jenis maupun peruntukan serta kuota akan dapat membantu kelestarian ikan-ikan lokal. Penentuan zonasi dan konservasi juga merupakan alternatif pengelolaan lainnya.

Pembudidayaan ikan dengan benih yang berasal dari daerah lain juga dapat menyebabkan tersebarnya jasad patogen dari daerah luar, kasus mewabahnya KHV merupakan kejadian dari peristiwa ini. Disadari atau tidak ikan mas yang berasal dari daerah wabah merupakan pemicu terjadinya penyakit di daerah setempat sehingga beberapa jenis ikan cyprinid menjadi punah. Pelarangan distribusi ikan-ikan dari daerah yang sedang berjangkit serta penggunaan vaksin pada ikan yang akan didistribusikan merupakan langkah yang dapat dilakukan dalam pengelolaan lingkungan budidaya.

Dibalik segi positif, program restocking merupakan kegiatan yang dapat menyebabkan terganggunya salah satu jenis ikan di daerah tertentu jika tidak dilakukan dengan cermat. Perbedaan latar belakang genetik antar ikan yang dijadikan bahan stocking dan ikan yang ada di daerah tempat dilakukan stocking akan membuat kerancuan genetik yang mempunyai peluang hilangnya allele tertentu yang adaptif terhadap lingkungan dari ikan aslinya, dan tidak menutup kemungkinan terjadinya kepunahan. Verifikasi data dasar genetik dari populasi ikan-ikan yang akan dijadikan bahan untuk penebaran dapat dijadikan alternatif awal pengelolaan ikan lokal.

Penggunaan obat-obatan, khususnya antibiotik, yang tidak sesuai dosis dan jenis yang dianjurkan dapat pula menjadikan jasad patogen resisten sehingga muncul jenis baru. Umumnya para pembudidaya suka mencoba-coba tanpa informasi yang tepat tentang penggunaan obatobatan dan bahan kimia untuk mengatasi suatu kejadian yang tengah dialaminya. Keadaan ini menyebabkan seringkali terjadi atau munculnya penyakit-penyakit baru di daerah budidaya sehingga akan mempengaruhi kesehatan ikan-ikan lokal yang ada di daerah tertentu. Penerapan CBIB (cara budidaya ikan yang baik) merupakan salah satu alternatif yang dapat dilakukan untuk membantu 
para pembudidaya melakukan eksperimen sendiri dalam mengatasi serangan penyakit ikan yang sedang terjadi.

\section{KESIMPULAN}

Penentuan jenis komoditas, pemilihan teknologi pembenihan yang sesuai, dan pengelolaan kesehatan lingkungan yang tepat merupakan aspek penting dalam kesuksesan pengembangan ikan-ikan lokal sebagai ikan budidaya yang potensial. Domestikasi dan budidaya ikanikan lokal dapat dijadikan cara untuk mempertahankan keberadaan plasma nutfah ikan-ikan lokal di suatu daerah sehingga dapat terus dimanfaatkan secara berkesinambungan.

\section{DAFTAR ACUAN}

Anderson, D.P. 1974. Fish Immunology. TFH Publications. Hongkong.

Direktorat Kesehatan Ikan dan Lingkungan. 2009. Pengendalian Penyakit Ikan. Direktorat Jenderal Perikanan Budidaya, Departemen Kelautan dan Perikanan. $123 \mathrm{hlm}$.

Haryono \& Subagja, J. 2008. Populasi dan Habitat Ikan Tambra, Tor tambroides (Bleeker, 1854) di Perairan Kawasan Pegunungan Muller Kalimantan Tengah. Biodiversitas, 9 (4): 306-309

Liu, J. \& Li, Z. 2010. The Role of Exotics in Chinese Inland aquaculture. In De Silva, S.S. \& Davy, F.B. (Eds). Success Story in Asian Aquaculture. NACA. Springer Science Business Media. B.V., p. 173-185.
Ministry of National Development Planning. 1993. Biodiversity Action Plan for Indonesia. Ministry of National Development Planning Agency, Jakarta, $141 \mathrm{pp}$.

Murjani. 2010. Program Pengelolaan Marine Culture. Bahan Presentasi Seminar Dampak Pencemaran Laut terhadap Produktivitas Sumberdaya Kelautan. Jakarta 14 Mei 2010, $13 \mathrm{hlm}$.

Nugroho, E. 2002. Pemanfaatan dan Pelestarian Plasma Nutfah Ikan Untuk Meningkatkan Produktivitas Perikanan Budidaya. Warta Penelitian Perikanan Indonesia, 6-13 hlm.

Nugroho, E. \& Kristanto, A.H. 2008. Panduan Lengkap Budidaya 15 Ikan Popular. Penebar Swadaya. Jakarta.

Pusat Data Statistik dan Infromasi. 2008. Kelautan dan Perikanan dalam angka 2008. PDSI, Sekretariat Jenderal, Departeman Kelautan dan Perikanan, $93 \mathrm{hlm}$.

Petrus, M., Erayani, S., Irmayuti, S., Magat, A.T.S., Mukhroni, Penni, Florensi, E., \& Jumat, E. 2008. Jenis Ikan Air Tawar dan Daerah Sebarannya di Kalimantan Tengah. Dinas KP Kalimantan Tengah, $305 \mathrm{hlm}$.

Utomo, A. Dj. 2008b. Status of Inland Water Fish Biodiversity in Indonesia. In Kartamihardja, E.S., Hartoto, D. I., Kamal, M.M., Husnah, Hernroth, L., \& Hem, S. (Eds). Proceeding International Conference on Indonesian Inland Waters. Book 2: General Papres, 1718 November 2008, Palembang. Res. Inst. For Inland Fisheries, B9-B15. 